IZA DP No. 7351

Sharp Teeth or Empty Mouths?

Revisiting the Minimum Wage Bite with Sectoral Data

Andrea Garnero

Stephan Kampelmann

François Rycx

April 2013

Forschungsinstitut

zur Zukunft der Arbeit

Institute for the Study

of Labor 


\title{
Sharp Teeth or Empty Mouths? Revisiting the Minimum Wage Bite with Sectoral Data
}

\author{
Andrea Garnero \\ ENS, Paris School of Economics \\ and Université Libre de Bruxelles, SBS-EM (CEB, DULBEA) \\ Stephan Kampelmann \\ Université Libre de Bruxelles, SBS-EM (CEB, DULBEA) \\ François Rycx \\ Université Libre de Bruxelles, SBS-EM (CEB, DULBEA) \\ and IZA
}

Discussion Paper No. 7351

April 2013

IZA

P.O. Box 7240

53072 Bonn

Germany

Phone: $+49-228-3894-0$

Fax: +49-228-3894-180

E-mail: iza@iza.org

\begin{abstract}
Any opinions expressed here are those of the author(s) and not those of IZA. Research published in this series may include views on policy, but the institute itself takes no institutional policy positions. The IZA research network is committed to the IZA Guiding Principles of Research Integrity.

The Institute for the Study of Labor (IZA) in Bonn is a local and virtual international research center and a place of communication between science, politics and business. IZA is an independent nonprofit organization supported by Deutsche Post Foundation. The center is associated with the University of Bonn and offers a stimulating research environment through its international network, workshops and conferences, data service, project support, research visits and doctoral program. IZA engages in (i) original and internationally competitive research in all fields of labor economics, (ii) development of policy concepts, and (iii) dissemination of research results and concepts to the interested public.
\end{abstract}

IZA Discussion Papers often represent preliminary work and are circulated to encourage discussion. Citation of such a paper should account for its provisional character. A revised version may be available directly from the author. 


\section{ABSTRACT \\ Sharp Teeth or Empty Mouths? Revisiting the Minimum Wage Bite with Sectoral Data*}

The paper explores the link between different institutional features of minimum wage systems and the minimum wage bite. We notably address the striking absence of studies on sectorallevel minima and exploit unique data covering 17 European countries and information from more than 1100 collective bargaining agreements. Results provide evidence for a neglected trade-off: systems with bargained sectoral-level minima are associated with higher Kaitz indices than systems with statutory floors, but also with more individuals actually paid below prevailing minima. Higher collective bargaining coverage can to some extent reduce this tradeoff between sharp teeth (high wage floors) and empty mouths (noncompliance/noncoverage).

JEL Classification: J31, J33, J51

Keywords: minimum wage systems, collective bargaining, wage bite, sectoral data, Europe

Corresponding author:

Stephan Kampelmann

Université Libre de Bruxelles

CP-140

Avenue F.D. Roosevelt 50

1050 Brussels

Belgium

E-mail: stephan.kampelmann@ulb.ac.be

\footnotetext{
* The research in this paper has been funded by the European Trade Union Institute. We are particularly grateful to Maria Jespen, Torsten Müller and Vera Glassner of the ETUI who have provided extremely constructive support and advice. We also would like to thank Martin Bauer, Lorenzo Birindelli, Reinhard Bispinck, Gerhard Bröthaler, Angela Golino, Ilkka Kaukoranta, Lena Larsen, Lene Paludan Hastrup, Pekka Sauramo, and Sepp Zuckerstätter, as well as the participants of the Belgian Day for Labour Economists (2012) in Leuven and the Eurofound expert meeting on minimum wages (2013) in Dublin. Elina Huttunen provided excellent research assistance. Any errors are obviously our own. The sectoral data used in this paper can be downloaded at:

http://www.parisschoolofeconomics.eu/docs/garnero-andrea/sector_mw_database_gkr2013.xls
} 


\section{Minimum wages in Europe: room for debate}

On 10 January 2013, Jean-Claude Juncker, Prime Minister of Luxembourg and outgoing president of the Eurogroup (the group of countries belonging to the Eurozone), told the European Parliament that Europe needs 'a basis of social rights for workers, minimum social rights for workers, including of course one essential thing, a minimum wage - a legally compulsory minimum wage in the Eurozone member states'. The European Commission issued also a series of statements in favour of an EU-wide approach to minimum wages. In April 2012, for example, the EU commissioner in charge of social affairs argued that 'setting minimum wages help prevent a destructive race to the bottom in the cost of labour, and are an important factor in ensuring decent job quality ${ }^{1}$. Similar arguments were put forward by the Party of European Socialists Congress, which called for 'decent minimum wages' by introducing an 'EU target for the minimum wage in terms of GNP per capita'.

The EU, however, has small leverage to implement a European approach to minimum wages because it lacks any official competence to issue directives or regulations concerning wage polices. In this area, the European Commission can only promote its agenda through recommendations and the Open Method of Coordination (i.e. by setting objectives that are politically but not legally binding). For example, it has recommended wage floors in order to close the gap between male and female wages in Austria (Hermann, 2005).

In addition to a lack of competence at the European Commission, the main factor that has worked against a European approach is the absence of a clear consensus at the European level concerning whether the benefits of harmonising minimum wage policies outweigh the costs. The trade unions, for instance, are far from unanimous in their support for European legislation that would impose statutory minimum wages everywhere in Europe. In particular, many countries where there is no statutory minimum wage are against a European scheme. Objections are notably very strong in Austria, Italy, and the Nordic countries (Lismoen, 2006). On the other hand, trade unions in countries such as Germany and Spain favour a European approach to the issue (Eldring and Alsos, 2012; Bosch and Kalina, 2010). Unsurprisingly, the European Trade Union Confederation has yet to develop a clear stance on the issue of an EU-wide minimum wage.

The usual argument put forward by both employers and the unions against a statutory minimum wage is that it could undermine the autonomy of the social partners and thereby jeopardise the entire bargaining process. Unions in particular fear a weakening of collective bargaining or exposing workers to political arguments in which minimum wages could become one of the adjustment variables. And ultimately, unions fear that a statutory minimum wage, which would probably be closer to wages in the lowest paid sector to avoid negative effects on employment, will reduce wages across the entire economy and therefore also in sectors where unions are strong. Many 
unions therefore advocate a minimum wage for workers not covered by collective agreements, but often insist more on the extension of collective bargaining than on statutory minima. The most notable exception is Germany where unions and political forces are discussing the adoption of a statutory minimum wage to counterbalance the effect of decreasing coverage of collective agreements and the increase in mini-jobs (low-wage jobs). ${ }^{3}$

Much of the antagonism inspired by the idea of a harmonised minimum wage policy in Europe stems from the fact that the current minimum wage arrangements differ widely among European countries (Machin, S. and A. Manning, 1997; Eyraud and Saget, 2005; Grimshaw, 2013). On the one hand, a European minimum wage is seen as desirable in countries without effective statutory minima and where collective bargaining agreements also fail to provide sufficient protection from wage dumping. On the other hand, countries with apparently effective collective bargaining institutions perceive a European approach as a threat to an established and functioning system (Eldring and Alsos, 2012). What both advocates and opponents of a European minimum wage policy lack is empirical evidence that compares the different national arrangements with respect to their impact on a series of labour market outcomes.

By and large, the academic literature on minimum wages has been dominated by protracted debates on the size of potential employment effects, especially in the United States (Brown et al, 1982; Card and Krueger, 1995; Cahuc and Zylberberg, 2004; Neumark et al., 2013). The link between different minimum wage institutions and labour market outcomes has hardly been studied until very recently (Boeri, 2012; Grimshaw, Bosch and Rubery, 2013). Despite scarce evidence, some academics have nevertheless started to push for the introduction of a European minimum wage. Most notably, in 2005 a group of eminent scholars on minimum wages signed a public call for a European minimum wage 'of at least 60 per cent of the average national wage' (Schulten et al., 2005). The possibility of a minimum wage - or at least some common rules - at EU level has also been raised and discussed by Vaughan-Whitehead (2010) and Grimshaw (2013) without, however, being able to compare the empirical performance of different minimum wage systems in terms of the degree of protection that minimum wages are supposed to provide. Focussing on the minimum wage bite, the objective of this paper is to provide not only a conceptual framework that helps us to think about the different trade-offs associated with alternative minimum wage policies, but also to present empirical evidence on the link between policy options and labour market outcomes.

The paper is structured as follows. Section 2 presents the conceptual framework of our approach by defining the term ‘minimum wages' (Section 2.1) and two complementary measures of the 'minimum wage bite': the Kaitz index (Section 2.2) and the share of individuals earning wages below prevailing minima (Section 2.3). Section 2.4 proposes a typology of minimum wage systems and a set of hypotheses on the link between the minimum wage bite and the main institutional features of these systems, namely the existence of a national statutory minimum wage and the coverage of sectoral-level collective bargaining. Section 3 describes the unique dataset including sectoral-level 
data on collective bargaining coverage and minimum wages that we use in this paper. We notably collected information on national-level minima from 11 countries and sectoral-level minima from more than 1100 sectoral agreements in 6 countries (Section 3.1). Sectoral collective bargaining coverage for all 17 countries has been computed with information from the European Company Survey (Section 3.2). The micro-level information on labour force composition and earnings stems from the latest three EU-SILC waves 2008-2010 (Section 3.3). Section 4 presents our regression framework allowing us to exploit the sectoral data in order to test the link between institutional features of minimum wage systems and our two indicators for the minimum wage bite. Our results suggest a trade-off between higher Kaitz indices and the extent of effective minimum wage coverage at the sectoral level. We also provide a series of robustness tests underlining the stability of our results (Section 4.3). The final section concludes.

\section{The minimum wage bite}

\subsection{What are 'minimum wages'?}

National statutory minimum wages have received much attention in Labour Economics and Industrial Relations, to such an extent that other types of wage floors are hardly ever analysed in these disciplines. However, when policy makers or trade unionists discuss 'minimum wages', they not only refer to statutory wage floors defined at the national level, but also to minimum wages that are defined as 'base rates' at the sectoral or occupational level. To give some examples, the collective agreement signed on 27 June 2007 in the Belgian chemical industry refers to a given amount by stating that 'ce salaire horaire minimum correspond au niveau le plus bas applicable, à savoir à la fonction de manoeuvre ordinaire. ${ }^{4}$ Also, the administrators of the German Mindestlohndatenbank compiled by the Wirtschafts- und Sozialwissenschaftliche Institut (WSI) clearly state that 'Tariflöhne sind Mindestlöhne, . For the case of Austria, Hermann (2005) calls sectoral-level wage floors 'minimum wages' by saying that 'in Österreich stellt der Mindestlohn die niedrigste Lohngruppe in den jeweiligen Kollektivverträgen dar' (p. 8) ${ }^{6}$. As can be inferred from these examples, practitioners and minimum wage experts refer to sectoral base rates as 'minimum wages'. More precisely, it is the wage assigned to the lowest category in collectively negotiated pay scales that should be interpreted as the relevant minimum wage: for all workers covered by a given agreement, it is in principle not possible to pay any of them below the rate that has been negotiated for the very bottom of the pay scale.

The almost exclusive focus on data collected within the group of countries with national statutory minimum wages is problematic because the labour market consequences of minimum wages might differ depending on whether they are defined at the national or sectoral level, or on whether they are imposed by the government or negotiated through collective bargaining. As a consequence, 
we know surprisingly little about the consequences of fundamental issues like whether the minimum is defined for the entire labour force (in the case of a national statutory minimum wage with no exemptions) or only a part of it (for instance, by a sectoral minimum that binds only trade union members). The few empirical studies that scrutinise the process through which minima are determined suggest that institutional arrangements matter: Boeri (2012), for example, has shown that national wage floors that are legislated unilaterally by the government are typically lower than those settled with closer involvement of the social partners. Moreover, Schulten (2012a) and Grimshaw and Bosch (2013) provide some evidence on the relationship between collective bargaining and the level of minimum wages, but the small samples in these studies do not allow us to draw robust conclusions.

\subsection{The Kaitz index}

When scholars or practitioners evaluate the impact of a given wage floor, they frequently refer to this impact as the 'bite' of a minimum wage. This notion can be linked to two statistical indicators, namely the 'Kaitz index' and the share of workers earning wages below the prevailing minima (Kaitz, 1970). As we will explain below, the information conveyed by each of these two indicators is different and only a combination of the two allows us to reflect on what is meant by the 'bite' of a minimum wage.

A direct comparison of absolute levels of minimum wages is not meaningful if countries differ in terms of labour productivity, prices or wage levels. The Kaitz index addressed this issue and is defined as the ratio of the minimum wage to the average wage of the working population. The index is thus a measure of the 'bite' of the minimum wage: small values indicate that the wage floor is a long way from the centre of the earnings distribution and its impact therefore potentially low; conversely, a high Kaitz index reveals that the minimum wage is close to the centre of the distribution and that it potentially affects a larger number of employees. It should be noted, however, that the Kaitz index alone does not allow us to draw any conclusions about whether a given level of the minimum wage is economically desirable or not: this question can be addressed only with additional information, such as the structure of wage costs and the productivity of different types of workers. In addition, as Dolado et al. (1996) point out, the Kaitz index may misrepresent the impact of minimum wages in countries where other institutions such as benefit systems act as effective wage floors (ibid., p. 325).

In countries in which minimum wages are determined not at the national but at the sectoral level - such as in Germany, Italy or the Nordic countries - the computation of Kaitz indices is relatively time-consuming due to the existence of numerous minima negotiated at sectoral level. But even for countries with a single national statutory minimum it can be advisable to calculate separate Kaitz indices for different wage or skill groups in order to reflect the fact that the minimum wage 
bites deeper for lower paid employees (in this case the numerator of the index is the same for all employees, but the denominator decreases if one considers a group of employees with lower average earnings). In order to improve its comparability, several adjustments to the basic Kaitz index have been proposed in the literature:

- Although many analysts compute the index with average earnings as denominator, using median earnings might yield more comparable results. The reason for this is that countries with higher wage dispersion also have lower minimum wages (OECD, 1998). A Kaitz index based on median earnings is less affected by the shape of the overall wage distribution than an index based on average earnings.

- The composition of the population affected by the Kaitz index might differ across countries; it is therefore sometimes advisable to compare indices for groups with similar characteristics (such as sector of activities, occupation, educational attainment, contract type, age or gender).

- Most European countries apply lower sub-minima for young or inexperienced workers (for example, teenagers), mainly in an attempt to curb potential disemployment effects for these groups. International comparability requires the use of different Kaitz indices if the question at hand focuses on specific groups affected by sub-minima.

- International comparisons of Kaitz indices are sensitive to the inclusion of bonuses, overtime and other additional payments; countries in which the incidence of such payments is large will display a non-adjusted Kaitz index (in other words, excluding additional payments) that overestimates the effective bite of the minimum wage.

- Conversely, the basic Kaitz index can lead to flawed comparisons if net earnings are used instead of gross earnings: the net Kaitz index risks capturing cross-country differences as regards the progressivity of tax systems rather than the relative level of the minimum wage as such.

- Finally, it is important to take institutional differences into account when comparing Kaitz indices. For instance, national labour market institutions differ in the extent to which hikes in the minimum wage are transmitted further up in the wage structure. As a consequence, Dolado et al. (1996) argue that it may be advisable to analyse changes over time than crosscountry differences, especially in situations of considerable institutional diversity between countries.

To the extent that our data allow, the empirical results presented in Section 4 take these observations into account. First, our Kaitz indices are based on median wages instead of average wages; second, since we analyse the impact of minimum wages at the sectoral level, we calculate Kaitz indices based on the sectoral-level median wage. In the case of countries in which wage floors are determined at the sectoral level, both the numerator and the denominator include sectoral-level information. Third, we tested whether our results are sensitive to the exclusion of young workers, for whom lower minima 
are defined in most countries. Fourth, our Kaitz indices are based on gross earnings, including social benefits and other benefits. This means that our measures yield information on the impact of the relative size of the minimum wage as it is commonly defined (in other words, including benefits) but before taxes. Fifth, in order to assess differences in national market labour our data on Kaitz indices include not only cross-country variability, but also within-country variability (between sectors and across time).

\subsection{The share of individuals below the minimum wage}

The Kaitz index alone cannot give a complete picture of the minimum wages bite: a relatively high index does not necessarily mean that many workers are actually paid at or above the minimum wage. There are many factors that could lead to the opposite outcome: an extremely compressed wage distribution; a substantial fraction of jobs that are not covered by prevailing minimum wage rules; or the occurrence of hourly wages that are not compliant with existing legislation or collective agreements. The case study evidence evaluated by Grimshaw et al. (2013) documents the extent of noncompliance in several European low-pay sectors and distinguish between different forms of noncompliance ranging from 'outright noncompliance' and 'exploitative wages' to 'silent acceptance' of subminimum pay by weak trade unions (Grimshaw et al., 2013; p. 233-234). While it is therefore true that a high Kaitz index is like a potentially sharp tooth indicating a strong 'bite' of the minimum wage, one also has to check whether the mouth of minimum wage rules is not empty due to issues such as noncoverage and noncompliance.

A complementary heuristic for the analysis of the minimum wage bite is therefore the distribution of workers with respect to the minimum wage. In this paper, we use the proportion of employments below the minimum wage as complementary indicator: the more workers are paid below the existing wage floor, the lower the bite of the minimum wage. This share can also be interpreted as a measure of noncoverage and/or noncompliance (in practice the two phenomena are often hard to distinguish).

There is little comparative research on the amount of jobs below prevailing minima; in particular, we are not aware of any research that links the incidence of such jobs to the characteristics of minimum wage systems. Figures computed by the US Bureau of Labor Statistics, however, give an idea of the size the underlying phenomenon in the United States: according to statistics on the distribution of workers paid at hourly rates in 2011 (a group that comprises around 75 million individuals), 1.7 million earned exactly the prevailing Federal minimum wage of $\$ 7.25$ per hour. The number of workers below the minimum wage was 2.2 million. Together, these 3.8 million workers with wages at or below the Federal minimum made up 5.2 per cent of all hourly-paid workers (Bureau of Labor Statistics, 2012). While the bite of the US Fair Labor Standards Act is therefore apparently substantial in light of 1.7 million jobs earning exactly the prevailing minimum wage, the fact that even more workers earn wages below the wage floor qualifies this conclusion. 


\subsection{Institutional diversity and the minimum wage bite}

In this section we discuss how different institutional features of minimum wage systems might be related to the minimum wage bite. The institutionalist literature on minimum wages so far has focused almost exclusively on systems in which wage floors are defined by national statutory minimum wage legislations. The focus of this literature has therefore been to account for different outcomes (such as the relative level of statutory minimum wages) by looking at differences between statutory systems, either across countries or across time. Existing empirical evidence notably suggests that in countries with statutory minimum wages a higher level of collective bargaining coverage is associated with relatively higher levels of minimum wages (Eyraud and Saget, 2005; Funk and Lesch, 2005; Boeri, 2012; Grimshaw and Bosch, 2013). This might be due to the fact that countries with higher collective bargaining coverage tend to have more egalitarian wage structures in which the median lies closer to the minimum wage, leading in turn to a higher Kaitz Index. Another explanation is that a higher level of collective bargaining coverage is associated with stronger trade-union influence on the level of the statutory minimum wage (for example, in negotiations by tripartite commissions).

In this paper we extend the analysis to countries in which wage floors are determined at the sectoral or occupational level through collective bargaining. Collectively agreed minimum wages at the sectoral level are sometimes considered to be 'functional equivalents' of statutory wage floors (Schulten et al., 2006), but unfortunately empirical evidence comparing the two types of systems is extremely rare. Given the importance and interactions between collective bargaining coverage and the type of minimum wage that prevails in a given system (Grimshaw, 2013); we therefore propose to distinguish European countries with the help of a typology including both elements:

- Collective bargaining coverage: the degree of coverage might influence both the relative level of the minimum wage and the incidence of jobs below and above the wage floor.

- National statutory minimum wage versus sectoral collectively bargained minima: whether minimum wages are determined nationally as statutory wage floors or through collective bargaining at sectoral or occupational level might also influence the minimum wage bite.

It should be noted that these two features are not entirely independent of each other. Indeed, a range of studies underline that the centralisation and coverage of collective bargaining tends to be higher in countries without statutory minima (Schulten et al, 2006; Vaughan-Whitehead, 2010; Eldring and Alsos, 2012). This observation is confirmed by our data: collective bargaining coverage is 31 percentage points higher in countries in which minimum wages are determined through collective bargaining at the sectoral level (see Section 3). In some cases, statutory minimum wages can be the consequence of low levels of collective bargaining if policymakers see them as an instrument to protect otherwise vulnerable workers. This explanation seems to account for the minimum wage 
policies adopted by Central and Eastern European countries where collective bargaining institutions were so weak during the transition to capitalist labour markets that almost all countries installed statutory wage floors in order to protect workers against excessive wage dumping.

Some minimum wage experts stress the heterogeneity of 'a host of different arrangements and national models' (Eyraud and Saget, 2005; p. 2) and it is of course possible to add more features to our typology in order to capture more of the institutional diversity between countries. For instance, one might split up the group of countries with statutory minimum wages according to the process through which the wage floors are determined (automatic adjustment to inflation, as in Belgium or France; bi- or tripartite negotiations, as in Estonia or Ireland; and determination by the state after consultation with the social partners, as in Portugal). The behaviour of the involved actors might also lead to different outcomes within the same type of minimum wage system. The strategy of some national trade union confederations of defining universal minimum wage target is a case in point. Even though there is no statutory minimum wage and bargaining takes place at the sectoral level in countries like Austria and Denmark, national campaigns such as the Austrian 'Kampagne 1.000-EuroMindestlohn' (cf. Hermann, 2006) or the Danish union target of 13.80 euros per hour (WestergaardNielson, 2008) introduce a degree of centralisation into an otherwise decentralised minimum wage system without necessarily changing the institutional set-up.

While therefore somewhat desirable on theoretical grounds, taking all the diversity on board leads inevitably to heavy data requirements when it comes to empirical hypothesis testing: the finer the distinctions between national models, the more observations and inter-category variability are required in order to produce statistically sound results. Confronted with this trade-off, we decided to focus on collective bargaining coverage and the opposition between statutory and collectively bargained minima, a distinction that allows us classify minimum wage systems with respect to the potential minimum wage bite (see Table 1). In particular, we hypothesise that different types of minimum wage systems are associated with varying degrees of minimum wage bite:

- No bite: a minimum wage systems that has neither a statutory minimum wage nor sectoral/occupational agreements that cover most of the workforce is likely to be associated with relatively low minimum wages and a considerable proportion of jobs paid below prevailing minima.

- Equivalent bite: statutory minimum wages and sectoral agreements with high coverage are sometimes regarded as functional equivalents (Schulten, 2012) providing an intermediate level of protection against low wages. Empirical evidence for the equivalence of the two types of minimum wage system is, however, so far not available.

- Dual bite: a combination of a statutory wage floor and wide collective bargaining coverage is hypothesised to be associated with relatively higher minima and fewer uncovered jobs. 
[Insert Table 1 here]

In order to be able to compare the minimum wage bite associated with different types of minimum wage systems, the empirical analysis in this report is based on a representative sample of seventeen European countries. The country sample has been selected in order to include (a) countries with and without national statutory minimum wages; (b) different levels of collective bargaining coverage; (c) countries from different sub-regions (Nordic countries, Southern Europe, Continental Europe, Central and Eastern Europe); and (d) both small and big countries. The complete sample includes Austria, Belgium, Bulgaria, Cyprus, Denmark, Estonia, Finland, France, Germany, Hungary, Ireland, Italy, Latvia, Portugal, Romania and the United Kingdom.

Table 2 applies our typology of minimum wage systems to these seventeen European countries. The empty square in the upper left corner means that all European countries provide at least some level of protection against low pay. Twelve of the eighteen countries in our sample are classified into one of the two squares associated with equivalent levels of protection: Latvia, United Kingdom, Ireland, Bulgaria, Estonia, Hungary, Portugal and Poland have a statutory minimum wage but low levels of collective bargaining coverage, while Austria, Finland, Denmark and Italy have no statutory minima but high coverage. Belgium and France are associated with a dual minimum wage bite, although in practice the French system provides no more protection than the two groups with equivalent bite, given that sectoral-level agreements often contain minimum rates that are actually below statutory wages (Gautié, 2010). The four remaining countries occupy intermediate positions: Romania arguably provide somewhat stronger protection than the other countries with statutory minimum wages due to the relatively high level of bargaining coverage. ${ }^{7}$ Conversely, the low coverage rates in Cyprus and Germany could mean that their minimum wage systems provide lower minimum wage bites compared to the other countries without statutory minimum wages. The weak position of the German minimum wage system in our table reflects of course the on-going debate on the introduction of a national minimum wages in this country, but it also illustrates why this debate is probably livelier in Germany than in most other European countries.

[Insert Table 2 here]

\section{Data sources and descriptive statistics}

\subsection{Statutory and collectively bargained minimum rates}

For all countries with statutory minimum wages except Cyprus, information on the level and evolution of wage floors has been collected from the March 2012 edition of the WSI Mindestlohndatenbank. ${ }^{8}$ The minimum rates have been collected and converted into euro amounts for 
all years with available microdata (see below). This step leads to 28 country-year observations from countries with statutory minimum wages at the national level.

In light of the institutional set-up of the seven countries in our sample that do not have a national statutory minimum wage (Austria, Belgium, ${ }^{9}$ Cyprus, ${ }^{10}$ Denmark, Finland, Germany and Italy), access to minimum wage data is considerably more problematic. Indeed, this information had to be collected manually from sectoral-level collective bargaining agreements. More precisely, we extracted from each agreement the wage assigned to the lowest category in collectively negotiated pay scales. While this definition of a sectoral minimum wage is straightforward, it should be noted that the elaborate categorisations that are found in many collective agreements render the identification of a given sectoral minimum wage relatively complicated. Indeed, in most agreements different pay scales co-exist: separate nomenclatures are often defined for blue- and white-collar workers; specific scales are included for apprentices or young workers who enter the labour market; and even where a unique pay scale exists it is often differentiated by variables such as occupational groups, work-post nomenclatures and seniority levels. In order to come closest to the conception of sectoral minimum wages as 'the pay rate defined for the lowest wage category', our database contains information on the pay rate of the lowest of any category that figures in all the pay scales in a collective agreement, with the exception of pay scales for apprentices and young workers. In practice, in the vast majority of agreements this boils down to the pay rate that applies to workers with no seniority and who are classified in low-status occupations at the bottom of organisational hierarchies ('manoevre ordinaire', 'Hilfsarbeiter' and so on).

It should be noted that the number of collective agreements signed in most countries is substantial: in Germany alone there are around 64,300 valid agreements, although most of them are signed at the company and not at the sectoral level. We therefore decided to collect minimum rates from a representative sample of collective agreements in each country and to use them to compute average minima at the one-digit level of the Statistical Classification of Economic Activities in the European Community (NACE). We notably extracted minimum rates from around 325 collective agreements from Austria (referring to wages in 2009); 150 from Belgium (wages in 2007); 105 from Denmark (wages in 2007, 2008 and 2009); 210 from Finland (wages in 2007, 2008 and 2009); 80 from Germany (wages in 2007); and 240 from Italy (wages in 2007, 2008 and 2009). In order to ensure the representativity of the sectoral-level minima in the final dataset, the calculation of average minimum rates at the one-digit level of the NACE takes into account the relative employment shares of the more than 1100 sampled sectors. ${ }^{11}$ This procedure produced 169 sector-year observations from countries without statutory minima.

The absolute levels of average minimum wages in each country are summarised in Table 3 . We observe a wide span ranging from less than 2 euros per hour in the four Central and Eastern European countries in our sample to minima that are more than five times higher in Denmark and Italy. Table 3 
also shows the average Kaitz index in each country over the period 2007-2009 (for countries with national minima the index corresponds to the weighted average of sectoral Kaitz indices and therefore masks the intersectoral variations of minimum wages). The average levels of Kaitz indices are closer to each other than the absolute minima: the majority of national Kaitz indices lie between 45 and 55 percent. We also observe that the Central and Eastern countries have the lowest minimum wages in both absolute and relative levels (Kaitz Indices below 50 percent); but the regional differentiation is less clear than for the absolute levels given that Poland has higher levels in 2008 and 2009, whereas Ireland (in 2008) also display values below 50 percent. All observations from countries without statutory minimum wages lie above 50 percent, including an extremely high value for Italy. In fact, the high Kaitz indices for Italy indicate that sectoral minima appear to lie relatively close to the corresponding median wages.

\subsection{Collective bargaining coverage}

Since our dataset includes information on minimum wages at the sectoral level, it was also necessary to collect data on collective bargaining coverage at the same level. While data on country-level coverage is widely available, for instance in the ICTWSS database ${ }^{12}$, we had to compute comparative sectoral collective bargaining coverage from survey data. For this purpose we used the 2009 wave of the European Company Survey, a large-scale organisational survey carried out by the European Foundation for the Improvement of Living and Working Conditions (EUROFOUND) every 5 years. The survey contains on average 905 company-level observations from 30 countries. In order to estimate sectoral collective bargaining coverage in the 17 countries in our sample, we used the information on a) the proportion of employees within companies covered by collective bargaining; b) whether collective bargaining refers to the company, sectoral or national level; and c) whether employers are able to pay salaries below the levels fixed by collective bargaining agreements. We then used this information to calculate averages at the one-digit NACE level of the proportion of employees who are covered by sectoral or national bargaining agreements that cannot be undercut.

The national averages of this variable are listed in Table 3. The collective bargaining coverage is 31 percentage points higher in countries in which minimum wages are determined through collective bargaining at the sector level, reflecting a well-known relationship we already mentioned above. But even if coverage and statutory floors may be historically related, over short time periods they can arguably be treated as being independent since it is costly and politically difficult to switch from one system to another (witness the slow progress towards implementation in the German debate on the introduction of a national minimum wage since the mid-2000s). This short-run exogeneity is relevant for this study because the regressions presented in Section 4 include both the coverage rate and the existence of a national minimum rate as explanatory variables. Since our sample includes 
three years (2007-2009), the potential long-run interdependence between coverage rates and statutory minima is less of a concern in our case.

\subsection{Earnings and individual characteristics}

The representative micro-level data we used stem from the harmonised survey of European Statistics on Income and Living Conditions (SILC). For the seventeen countries in our sample, we used the available waves collected in 2008, 2009 and 2010 containing information on income variables for the years 2007-2009. The EU-SILC data contain labour market information for a range of European countries and are designed as a household-level survey allowing one to calculate inequality and poverty indicators, in particular the so-called Laeken indicators such as the poverty rate, in-work poverty, or the Gini index (see Atkinson et al., 2002). The EU-SILC data contain detailed information on job characteristics such as earnings, employment type, and employer characteristics. On average, the micro-level information in our sample is based on 6792 individual observations per country and year (for the number of observations per country see Table 3).

The income variable used in the regression analysis is gross hourly wages. The latter have been calculated at the individual level by dividing gross monthly income - i.e. monthly income before the deduction of taxes and including social contributions paid by the employee - by the working hours the individual declared for the corresponding income period. We calculated this variable for all workers in the SILC except for individuals who declared themselves self-employed; our analysis therefore includes individuals working part-time and all salaried employment. This is slightly different from other studies on minimum wages, which look only at full-time workers or focus exclusively on individuals paid hourly wages as opposed to monthly salaries (Schulten et al., 2006; Vaughan-Whitehead, 2010; US Bureau of Labor Statistics, 2012).

The precision of our earnings measure therefore depends on the quality of both the income and the hours measures. In the context of minimum wage research, especially the imperfect measurement of working hours has received particular attention (Hermann, 2006). In the SILC, both numerator and denominator of the wage variable are self-reported survey data and therefore subject to the usual disclaimers. While sometimes criticised as being less precise than administrative data collected from company records or fiscal authorities, our earnings measure taps into the information of the individuals actually working on the job and who therefore have knowledge on unrecorded working hours that by definition is not available in administrative records. In the context of research on minimum wages, an important advantage of survey data is that employers may have incentives not to disclose if they pay wages that are below prevailing minimum rates. For instance, the case studies in Grimshaw (2013) suggest that employers in the security sector circumvent minimum wage 
legislation by declaring artificially low working hours so that monthly full-time wages appear to be compliant with existing minima. This means that noncompliance is arguably much more difficult to measure with company records or payroll figures communicated to tax authorities than with survey data.

Table 3 shows the national averages for the share of workers below minimum wages defined as individuals earnings less than 75 per cent of the prevailing wage floor ${ }^{13}$. There is no clear regional stratification with respect to this variable.

It should of course be noted that the usual disclaimers regarding cross-country comparisons apply also in our case: the variations between the countries might not represent genuine differences between the two types of systems but instead be related to other types of heterogeneity. For instance, this heterogeneity can be related to institutional arrangements affecting the minimum wage such as national idiosyncrasies in the wage setting mechanism, extension rules and centralisation of bargaining (cf. Grimshaw et al., 2013) or cross-country variations in the composition of the labour force in terms of occupational composition and educational attainment. The latter may be related to the Kaitz index, a factor that some empirical studies are not able to address due to lack of data (the cross-country analysis in Boeri (2012), for instance, does not control for variations in occupational and educational composition). Our regressions control for variations in the respective shares of bluecollar workers, white-collar workers and managers based on ISCO categories and three levels of educational attainment based on ISCED categories (for the definitions see Table 3).

In light of the fact that many minimum wage earners are women (see Rycx and Kampelmann, 2012), it is also important to account for intra-European variations in the share of women within the labour force, a measure that ranges in our sample from 44 percent in Italy to 53 percent in Estonia (see Table 3). Other compositional factors that vary across countries and for which we control in the regression analysis in the next section are: the distribution of workers across sectors of activity at onedigit level of the NACE; the share of the public sector employment in the country; the share of fixedterm contracts; the age composition (we distinguish between six age groups: 15 to 24 years; 25 to 29; 30 to 34; 35 to 44; 45 to 59; and above 60 years); finally, since part-time workers are more likely to receive minimum wages in certain countries (see Rycx and Kampelmann, 2012), we also control for variations in the national share of jobs with less than 35 working hours per week.

[Insert Table 3 here] 


\section{Regression analysis}

We now turn to our regression results. All results report standard errors that are robust to heteroskedasticity and autocorrelation and contain specifications with and without the set of control variables described above, although space constraints do not allow us to report all coefficients. The models including control variables also contain year dummies in order to capture business cycle effects. The main explanatory variables on which we will focus in the discussion are the two key features of minimum wage systems, namely the existence of a national statutory minimum wage and the degree of collective bargaining coverage at the sectoral level.

\subsection{The minimum wage bite I: the level of the Kaitz index}

As hypothesised in Section 2.2, the Kaitz index is likely to be positively correlated with the extent of collective bargaining coverage. It should be noted, however, that it is unclear whether collective bargaining coverage affects the numerator or the denominator of the index: on the one hand, higher coverage is likely to be associated with higher bargaining power and more favourable terms in collective agreements defining sectoral bargaining; in some countries which statutory minima wider bargaining coverage might also improve trade union power in the process of setting the national minimum wage. But higher coverage also increases the share of workers falling under collective agreements and therefore leads to a more compressed wage distribution in general.

Another common hypothesis among many trade unionists is that the Kaitz index tends to be lower in systems with a national statutory minimum wage. The results presented in this section provide empirical facts in order to test these claims.

Figure 1 suggests a positive relationship between collective bargaining coverage and the sectoral Kaitz Index. But the figure also reminds us that the countries without statutory minimum wages have generally higher level of collective bargaining coverage. We used a simple regression framework to isolate the two effects; the dependent variable in this model is the Kaitz index at the sectoral level, the main dependent variables are the existence of a national statutory minimum wage and collective bargaining coverage (see

Table 4). The regression results indicate that both claims cannot be refuted: the existence of a national statutory minimum wage is indeed negatively related to sectoral Kaitz indices: the statistically significant difference between the two systems lies above 10 percentage points in models 3 and 4. Higher collective bargaining coverage is associated with higher Kaitz indices in model 4 excluding the set of control variables; in model 3 including controls the corresponding coefficient is also positive but not statistically different from zero.

This being said, models 3 and 4 do not account for the potential interaction between a national statutory minimum wage and collective bargaining coverage. Models 1 and 2 address this issue by 
including a corresponding interaction variable. The resulting changes in the coefficients are quite intuitive: first, the dummy variable for the national statutory minimum wage becomes insignificant and the negative effect of the national minimum is captured by a large and significantly negative coefficient of the interaction variable; second, the coefficient measuring the effect of collective bargaining coverage is now significant and much higher in models 1 and 2 . We interpret these results as indicators for (a) a much stronger link between collective bargaining coverage and the sectoral Kaitz index in systems without a national statutory minimum wage and (b) for the claim that at equal levels of collective bargaining coverage systems with national statutory minima are associated with lower Kaitz indices (for the case of an index of 0.5, model 2 suggests that the difference equals -0.035 $=0.23 * 0.5-0.3 * 0.5)$.

\section{[Insert Figure 1 and Table 4 here]}

\subsection{The minimum wage bite II: share of workers below wage floors}

A higher Kaitz index is often interpreted as indicating that the underlying minimum wage has a higher bite. The information on the relative size of the minimum wage should, however, be complemented with information on the share of employees who are paid below the minimum wage. The higher this share, the lower is the effective bite of the minimum wage.

How are our two indicators of the minimum wage bite related to each other? Figure 2 plots the shares of employees with wages below 75 per cent of the corresponding minimum wage against the Kaitz index in each sector. We observe a clearly positive relationship between the two variables. This suggests that a higher relative level of the minimum - an outcome typically favoured by trade unions - might have a downside if it is systematically associated with a higher share of individuals who are paid below the minimum wage. Moreover, Figure 2 indicates that the incidence of belowminimum wages is higher in countries without national minima - again a quite intuitive result. Surprisingly, the trade-off between a higher relative minimum wage and higher effective coverage is hardly ever discussed by either practitioners or scholars, arguably because data on this phenomenon was so far not available. We believe that this is a serious shortcoming and could lead to flawed policies: indeed, the graphical relationship in Figure 2 suggests a substantial trade-off.

Turning to our regression results, Table 5 shows estimations for models including the share of individuals earning wages below the prevailing minima as dependent variable. Models 8 and 9 suggest that this share is 5 percentage points lower in countries with statutory minimum wages. By contrast, the coefficients for collective bargaining coverage are not conclusive in these two models. In light of the apparent link between the Kaitz Index and noncoverage/noncompliance suggested by Figure 2, models 8 and 9 might suffer from an omitted variable bias. Indeed, the coefficient of 
determination in a specification including the Kaitz index among the explanatory variables (models 5 through 7 in Table 5) is at least 20 percentage points higher than in the models excluding the Kaitz index as explanatory variable. The models 5 and 6 also allow for the effect of the Kaitz index to differ among countries with and without a national minimum wage. The inclusion of the Kaitz index raises of course the concern that the results suffer from multicollinearity given that we have shown in the previous section that the Kaitz index is correlated with the other explanatory variables. This issue does not appear to be problematic in models 5 and 6 because the potentially collinear explanatory variables are all statistically significant. This suggests that the respective effects of the national minimum wage, collective bargaining coverage, the Kaitz index and the interaction variables are to some extent correlated but nevertheless correspond to distinct and identifiable relationships with the dependent variable. Our preferred specification is model 5 which also accounts for the potential interaction effect between national minima and collective bargaining coverage at the sectoral level.

The estimated coefficients for model 5 confirm that, ceteris paribus, the share of individuals earning wages below prevailing minima tends to lower in countries with statutory minima. If we suppose, for example, collective bargaining coverage of 0.7 per cent and a Kaitz index of 0.5 per cent, the proportion of individuals below the corresponding minimum would be $0.12+(-0.05+0.06) * 0.7$ $+(0.44-0.3) * 0.5=0.197$; the corresponding proportion in a system without national wage floor would be $-0.05 * 0.7+0.44 * 0.5=0.255$. We therefore estimate that in this case noncoverage is around 5.8 percentage points higher in systems without a national minimum wage. Two corollary results of our model are that (a) the link between higher levels of the Kaitz index and the incidence of workers paid below minimum wages is significantly weaker in systems with national wage floor; and (b) that sectors in which minima are defined through collective bargaining can compensate to some extent the undesirable effect of higher Kaitz indices through higher bargaining coverage.

[Insert Figure 2 and Table 5 here]

\subsection{Robustness tests}

We have run a large number of robustness tests and alternative specifications that cannot be all reported here; especially the number of plausible combinations of control and interaction variables is quite large. None of these tests modifies substantially the estimation results presented above. In this section we focus on what are arguably the most relevant robustness tests and examine whether our conclusions are modified: if regressions are estimated without countries with outlying values or systems (Section 4.3.1); once apprentices and very young workers are excluded from the sample (Section 4.3.2); if we use an alternative indicator threshold to measure the proportion of individuals 
below prevailing minima (Section 4.3.3); and, finally, if we use alternative data on collective bargaining coverage (Section 4.3.4).

\subsubsection{Exclusion of outlying observations}

Some of the sectors in our sample display levels of the Kaitz index that exceed 90 per cent. This notably the case of single sectors in Austria, Cyprus, France, Germany and the UK and for several Italian sectors. Given that the average Kaitz index in our sample is 55 per cent, we have tested whether our estimations are sensitive to the exclusion of these outliers (models 10 and 12 in Table 6 and model 14 in Table 7). The results of this test show that the sign and significance of the estimated coefficients is not altered if we eliminate Kaitz indices above 90 per cent from the sample; as one might have expected, only the size of the measured effects decreases somewhat with respect to the baseline model (the difference is at most 8 percentage points but for many coefficients much smaller).

A second set of outlying observations concerns the case of Belgium. The specificity of this country's minimum wage system is that it is the only one offering effective dual protection again low wages: it combines a national statutory minimum with high levels of collective bargaining coverage and binding wage floors defined in sectoral agreements. While the French system also combines a national minimum with sectoral bargaining, collective agreements in France often fail to increase the minima above the national level - indeed, many collective agreements include wage floors below the SMIC that are therefore not relevant minima (Gautié, 2010). The interpretation of the Belgian figures on sectoral minima is therefore slightly different compared to other countries in our sample, a difference that makes it worthwhile to test whether our conclusions change if Belgium is dropped from the sample. The results of this test correspond to models 11 and 13 in Table 6 and model 15 in Table 7. As can be seen, the estimated coefficients are clearly not sensitive to the exclusion of Belgium as none of them deviates substantially from the values in the baseline model.

[Insert Tables 6 and 7 here]

\subsubsection{Impact of young workers and apprentices}

Many countries and sectors differentiate applicable minima according to the employment status and age of individuals. This is notably the case for apprentices and employees younger than 18 and reflects the opinion shared by many policy makers and social partners that lower rates for these groups could curb negative employment effects. The reasoning behind the differentiation is that applying the same minimum rate to all employees would harm apprentices and young workers whose 
lack of experience is arguably associated with lower productivity compared to the rest of the workforce.

Due to the practical difficulty of identifying reduced rates for apprentices and young workers in all country- and sectoral-level minima included in our database, we have not been able to collect all prevailing sub-rates so that our results might be biased if the incidence of differentiated rates is high or extremely heterogeneous across minimum wage systems; Kaitz indices might be overestimated if reduced rates apply for a substantial part of the labour force.

In order to examine the scope of this issue, we have rerun all regressions after excluding apprentices and workers younger than 18 years from the SILC. While this procedure does not directly measure the impact of reduced rates on indicators such as the Kaitz index, it has the merit of assessing whether our conclusions regarding the rest of the labour force are robust. The regression outputs of this test correspond to model 17 in Table 7 and models 19 and 20 in Table. In light of the stability of all coefficients we conclude that the existence of sub-minima for young workers and apprentices does not affect our baseline results. ${ }^{14}$

\section{[Insert Table 8 here]}

\subsubsection{Alternative thresholds for proportion of workers below the minimum wage}

The third robustness test reported here is concerned with the validity of our second indicator for the minimum wage bite, namely the share of workers paid below the prevailing wage floors. To the extent that both income variables and the hours measure are prone to measurement errors, it might be worthwhile to assess whether our results are sensitive to alternative definitions of this indicator.

To address this issue, we have experimented with alternative thresholds for the share of workers below prevailing minima. While our baseline threshold of 75 per cent allows for an error margin of 25 percent before workers are falsely counted as being not covered and/or not compliant with existing minima, an alternative threshold of 85 per cent below the prevailing sectoral minima allows only for smaller error margin of only 15 per cent (model 17 in Table 7). Again, the estimated coefficients of this robustness test do not differ significantly from our baseline model.

\subsubsection{Alternative data on collective bargaining coverage}

Our data on sectoral collective bargaining coverage stems from the European Company Survey (see Section 3.2). An alternative and widely used reference for information on collective bargaining 
coverage is Jelle Visser's Database on Institutional Characteristics of Trade Unions, Wage Setting, State Intervention and Social Pacts (ICTWSS) ${ }^{15}$, a standard reference in the literature on labour market institutions that in turn compiles information from various international surveys and countryspecific sources (Visser, 2011). The major drawback of the ICTWSS for the question addressed in this paper is that the database only contains the national collective coverage; in contrast to the ECS, it does not allow account for sector-level heterogeneity in coverage. This means that sectoral-level regressions with the ICTWSS collective bargaining information rely on the assumptions that the proportion workers covered only at the sectoral level does not differ systematically across sectors and countries.

Despite this limitation and due to the ICTWSS's status as standard reference, we have used ICTWSS data corresponding to all country-year observations in our sample in order to test the robustness of our results. A comparison of the collective bargaining coverage in the ICTWSS and the ECS shows that the two are strongly correlated: the highly significant correlation coefficient between the two coverage variables equals 0.60 and means that the ECS variable is on average much lower than the ICTWSS. This is not surprising given that the latter contains also bargaining coverage at the company level whereas we defined our ECS variable as including only higher levels of bargaining.

Table 9 compares the regression results for our preferred specification with the sectoral Kaitz index as dependent variable. In the specification without interaction variable (models 3 and 22), the coefficient for the existence of a national statutory minimum wages is smaller when based on the ICTWSS data compared to the baseline model, whereas the size of the coefficient for collective bargaining coverage is higher and statistically significant. By contrast, in the specifications with interaction variables (models 1 and 21), the coefficient for the national minimum wage is much larger and significantly negative with the ICTWSS whereas the interaction and the collective bargaining variable are not significantly different from zero in model 21.

Table 7 shows the robustness tests for the specifications with the share of workers below minimum wage as dependent variable; model 16 corresponds to the regression based on the ICTWSS data for (national) collective bargaining coverage. While the sign and significance of all effects is similar to the baseline specification (model 5), the size of the collective bargaining variable is somewhat higher and the national minimum wage variable lower compared to the specification with sectoral ECS data.

To conclude, the regressions based on the ICTWSS data confirm a negative relationship between the existence of a national statutory minimum wage and the Kaitz index and provide additional evidence for the hypothesis that a higher level of collective bargaining coverage is associated with higher Kaitz indices. By contrast, the ICTWSS data fails to capture the interaction between collective bargaining coverage and the national wage floor. The relationships in our baseline 
specification with the share of workers with subminimum wages are also confirmed by the alternative regression with ICTWSS data, although the size of the effect of collective bargaining coverage appears to be higher. One should, however, bear in mind that the ICTWSS data does not capture intersectoral variation, especially the interaction between the national wage floor and sectoral minimum wage coverage are therefore likely to be misrepresented.

[Insert Table 9 here]

\section{Conclusion}

This paper is a conceptual and empirical contribution to a relatively recent debate on minimum wages, namely the increasingly vivid discussion on the introduction of a European-wide minimum wage policy. The current debate in Europe confronts opinions and attitudes that are conditioned by the different industrial relations systems in which they arise (Grimshaw, Bosch and Rubery, 2013). For instance, it is easy to see the link between the decreasing collective bargaining coverage that Germany experienced during the last decades and the widening acceptance of a national or European minimum wage policy by German trade unions. The conceptual contribution of the paper consists in a straightforward typology that allows us to distinguish European minimum wage systems with respect to the two key institutional features, namely (a) the existence of a national statutory minimum wage and (b) the degree of collective bargaining coverage at the sectoral level.

This typology is a useful tool to generate hypotheses about the link between different institutional configurations and the 'minimum wage bite'. While commonly associated with the size of the minimum wage relative to the median wage, we argued that the Kaitz index has to be complemented with an additional heuristic in order to obtain an accurate picture of this 'bite'. We advocate using the proportion of workers earning wages below the prevailing minima as a complementary indicator: having sharp teeth (i.e. a high Kaitz index) is clearly not enough to have a strong 'bite' if the system is empty mouthed (i.e. many individuals are actually paid subminimum wages).

The empirical contribution of the paper addresses the almost complete absence of empirical data on sectoral-level bargaining that characterises the literature and, by extension, renders the political discussion at the EU level prone to flawed decisions based on taken-for-granted assumptions about the performance of different minimum wage systems. We have tried to overcome this serious gap in the literature through extensive data collection combining micro-data from household and company surveys with institutional information; most importantly, we created a unique database with minimum wages collected from more than 1100 collective bargaining agreements written in six different languages and signed in seven different countries. 
A series of important conclusions emerges from our empirical analysis. First, our regression results provide empirical backing for the standard narrative put forward by trade union representatives according to whom (a) relatively higher levels of minimum wages can be obtained by boosting the coverage of collective bargaining and (b) national statutory minima are associated with relatively lower minimum wages. Second, this result is only one side of a policy trade-off that has so far been almost completely neglected: our empirical analysis shows that higher Kaitz indices are significantly associated with a higher proportion of individuals who actually earn wages below the prevailing minimum. Third, this negative side effect of relatively higher Kaitz indices appears to be significantly smaller in countries with national statutory minimum wages. In countries without a national wage floor, higher levels of collective bargaining can to some extent compensate for this difference - a finding that confirms the idea that different institutions can be functionally equivalent (Schulten, 2012) and generate an 'equivalent bite’ (see Table 1).

While of our results provide empirical evidence for certain claims used by policy makers and social partners, the widely neglected trade-off between higher minima and higher incidences of subminimum earners suggests that the Kaitz index alone is insufficient to measure the minimum wage bite; our results also highlight the problems of noncompliance and noncoverage that have so far received limited attention from scholars and policy makers. The new European minimum wage debate stands to gain by paying more attention to these outcomes and the way in which institutional features moderate the effect of wage floors in different national contexts.

\section{References}

Atkinson, Anthony.B., Bea Cantillon, Eric Marlier and Brian Nolan. 2002. Social Indicators. The EU and Social Inclusion, Oxford: Oxford University Press.

Boeri, Tito. 2012. 'Setting the minimum wage', Labour Economics, vol. 19(3): 281-290.

Bosch, Gerhard. and Thorsten Kalina. 2010.' Germany: What Role for Minimum Wages on Lowwage Work?' In: Vaughan-Whitehead, Daniel. (ed.). 2010. The Minimum Wage Revisited in the Enlarged EU, International Labour Office.

Brown, Charles., Curtis Gilroy and Andrew Kohen. 1982. 'The effect of the minimum wage on employment and unemployment', Journal of Economic Literature, 20: 487-528.

Bureau of Labor Statistics. 2012. Characteristics of Minimum Wage Workers: 201. U.S. Department of Labor.

Cahuc, Pierre and André Zylberberg. 2004. Labor Economics. Cambridge: MIT Press.

Card, David and Alan Krueger. 1995. Myth and Measurement: The New Economics of the Minimum Wage. Princeton: Princeton University Press. 
Dolado, Juan, Francis Kramarz, Stephen Machin, Alan Manning, David Margolis and Coen Teulings. 1996. 'The economic impact of minimum wages in Europe.' Economic Policy, 23: 319-370.

Eldring, Tine and Kristin Alsos. 2012. European Minimum Wage: A Nordic Outlook. Oslo: Fafo.

Eyraud, François and Catherine Saget. 2005. The fundamentals of wage fixing, Geneva: ILO.

Funk, Lothar and Hagen Lesch. 2006. 'Minimum wage regulations in selected European countries', Intereconomics, 41(2): 78-92.

Gautié, Jérome. 2010. 'France: towards the end of active minimum wage policy?', in VaughanWhitehead, Daniel. 2010. The Minimum Wage Revisited in the Enlarged EU, International Labour Office.

Grimshaw, Damian (ed.). 2013. Minimum Wages, Pay Equity, and Comparative Industrial Relations. London: Palgrave.

Grimshaw, Damian and Gerhard Bosch. 2013. Minimum wages and collective bargaining: A framework for examining multiple intersections, in Grimshaw, Damian (ed.). 2013. Minimum Wages, Pay Equity, and Comparative Industrial Relations. London: Palgrave.

Grimshaw, Damian, Gerhard Bosch and Jill Rubery. 2013. Minimum wages and egalitarian pay bargaining in comparative perspective, in Grimshaw, Damian (ed.). 2013. Minimum Wages, Pay Equity, and Comparative Industrial Relations. London: Palgrave.

Hermann, Christoph. 2005. 'Mindestlöhne in Österreich', FORBA Schriftenreihe 4/2005.

Hermann, Christoph. 2006. 'Minimum wages in Austria', in Schulten, Thorsten et al. 2006. Mindestlöhne in Europa. Hamburg: VSA-Verlag.

Kaitz, Hyman. 1970. 'Experience of the past: the national minimum wage', in US Department of Labor, Bureau of Labor Statistics: Youth unemployment and minimum wages, Bulletin 1657.

Kampelmann, Stephan, Andrea Garnero and François Rycx. Forthcoming in 2013. Minimum wages in Europe: does the diversity of systems lead to a diversity of outcomes? Research report. Brussels: European Trade Union Institute.

Lismoen, Håvard. 2006? 'Low-wage regulation in Scandinavia', in Thorsten Schulten et al. Mindestlöhne in Europa. Hamburg: VSA-Verlag.

Machin, Stephen and Alan Manning. 1997. 'Minimum wages and economic outcomes in Europe', European Economic Review, 41(3-5): 733-742.

Neumark, David, Ian J.M. Salas and William Wascher. 2013. 'Revisiting the minimum wageemployment debate: throwing out the baby with the bathwater?', NBER Working Paper 18681.

OECD. 1998. 'Making the most of the minimum: statutory minimum wages, employment and poverty', in Employment Outlook, Paris: OECD.

Rycx, François and Stephan Kampelmann. 2012. 'Who earns minimum wages in Europe? New evidence based on household surveys', European Trade Union Institute, Report 124. 
Schulten, Thorsten, Claus Schäfer, Reinhard Bispinck, Andreas Rieger, Beat Ringger, Hans Baumann, Michel Husson and Antoine Math. 2005. 'Theses for a European minimum wage policy', Conference 'Minimum Wages in Europe’, 21-22 April 2005, Zurich.

Schulten, Thorsten, Reinhard Bispinck and Claus Schäfer (eds). 2006. Mindestlöhne in Europa. Hamburg: VSA-Verlag.

Schulten, Thorsten. 2012. 'European Minimum Wage Policy: A Concept for Wage-led Growth and Fair Wages in Europe’, International Journal of Labour Research, Vol. 4, No. 1, pp. 85-103.

Vaughan-Whitehead, Daniel (ed.). 2010. The Minimum Wage Revisited in the Enlarged EU. Geneva: International Labor Office.

Visser, Jelle. 2011. 'ICTWSS: Database on Institutional Characteristics of Trade Unions, Wage Setting, State Intervention and Social Pacts in 34 countries between 1960 and 2007', Version 3, Amsterdam Institute for Advanced Labour Studies (AIAS), University of Amsterdam.

Westergaard-Nielsen, Niels. 2008. Statistical analysis and history of low-wage work in Denmark, in: Niels Westergaard-Nielsen (ed.) Low-wage work in Denmark, New York: Russell Sage Foundation. 
Table 1: Overview of minimum wage systems

\begin{tabular}{lll}
\hline & Low bargaining coverage & High bargaining coverage \\
\hline Sectoral/occupational MW & No bite & Equivalent bite \\
National statutory MW & Equivalent bite & Dual bite \\
\hline
\end{tabular}


Table 2: Overview of countries according to their minimum wage systems

\begin{tabular}{llll}
\hline & Low bargaining coverage & Medium coverage & High coverage \\
\hline Sectoral/occupational MW & - & Cyprus, Germany & Austria, Finland, Denmark, \\
& & & Italy \\
National statutory MW & Latvia, United Kingdom, Ireland, & Romania & Belgium, France \\
& Bulgaria, Estonia, Hungary, & \\
& Portugal, Poland, & \\
\hline
\end{tabular}


Table 3: Descriptive statistics of main variables at the country level (2007-2009)

\begin{tabular}{|c|c|c|c|c|c|c|c|c|c|c|c|c|c|c|}
\hline & $\begin{array}{c}\begin{array}{c}\text { Observations } \\
\text { per year }\end{array} \\
\end{array}$ & $\begin{array}{c}\text { SILC waves } \\
\text { used in } \\
\text { empirical } \\
\text { analysis } \\
\end{array}$ & $\begin{array}{c}\text { National } \\
\text { statutory } \\
\text { minimum } \\
\text { wage } \\
\end{array}$ & $\begin{array}{c}\text { Collective } \\
\text { bargaining } \\
\text { coverage }\end{array}$ & $\begin{array}{c}\text { Average } \\
\text { minimum } \\
\text { wage }\end{array}$ & $\begin{array}{c}\text { Average } \\
\text { Kaitz Index }\end{array}$ & $\begin{array}{c}\text { Share of } \\
\text { workers } \\
\text { below the } \\
\text { minimum } \\
\text { wage }\end{array}$ & $\begin{array}{c}\text { Share } \\
\text { of } \\
\text { women }\end{array}$ & $\begin{array}{c}\text { Blue collar } \\
\text { (ISCO 11- } \\
34 \text { ) }\end{array}$ & $\begin{array}{c}\text { White collar } \\
\text { (ISCO 41- } \\
52)\end{array}$ & $\begin{array}{c}\text { Managers } \\
\text { (ISCO 61- } \\
\text { 93) }\end{array}$ & $\begin{array}{c}\text { ISCED } \\
\text { levels } \\
0,1,2 \\
\end{array}$ & $\begin{array}{c}\text { ISCED } \\
\text { levels } \\
3,4 \\
\end{array}$ & $\begin{array}{c}\text { ISCED } \\
\text { levels } \\
5,6 \\
\end{array}$ \\
\hline Austria & 5409 & 2010 & no & 0.76 & 7.67 & 0.59 & 0.06 & 0.47 & 0.35 & 0.33 & 0.32 & 0.15 & 0.65 & 0.19 \\
\hline Belgium & 5438 & 2008 & yes & 0.64 & 9.32 & 0.63 & 0.06 & 0.44 & 0.40 & 0.31 & 0.30 & 0.21 & 0.37 & 0.42 \\
\hline Bulgaria & 5399 & 2008-2010 & yes & 0.33 & 0.63 & 0.42 & 0.01 & 0.50 & 0.35 & 0.28 & 0.37 & 0.14 & 0.55 & 0.31 \\
\hline Cyprus & 3429 & 2008-2009 & no & 0.23 & 4.65 & 0.52 & 0.05 & 0.50 & 0.41 & 0.28 & 0.31 & 0.17 & 0.40 & 0.43 \\
\hline Germany & 10744 & 2008 & no & 0.56 & 7.61 & 0.60 & 0.12 & 0.48 & 0.47 & 0.27 & 0.26 & 0.10 & 0.54 & 0.36 \\
\hline Denmark & 4373 & 2008-2010 & no & 0.52 & 14.21 & 0.65 & 0.08 & 0.47 & 0.43 & 0.24 & 0.33 & 0.22 & 0.46 & 0.32 \\
\hline Estonia & 5453 & 2008-2010 & yes & 0.10 & 1.61 & 0.43 & 0.01 & 0.56 & 0.49 & 0.20 & 0.31 & 0.09 & 0.50 & 0.41 \\
\hline Finland & 9399 & 2008-2010 & no & 0.79 & 8.92 & 0.59 & 0.03 & 0.51 & 0.45 & 0.26 & 0.29 & 0.13 & 0.47 & 0.41 \\
\hline France & 9863 & 2009-2010 & yes & 0.48 & 8.63 & 0.71 & 0.08 & 0.47 & 0.43 & 0.25 & 0.32 & 0.20 & 0.44 & 0.36 \\
\hline Hungary & 7690 & 2008-2010 & yes & 0.26 & 1.52 & 0.54 & 0.02 & 0.49 & 0.37 & 0.26 & 0.37 & 0.13 & 0.61 & 0.27 \\
\hline Ireland & 3681 & 2008-2009 & yes & 0.34 & 8.48 & 0.54 & 0.04 & 0.44 & 0.40 & 0.31 & 0.29 & 0.24 & 0.37 & 0.39 \\
\hline Italy & 13450 & 2008-2010 & no & 0.82 & 10.50 & 0.90 & 0.19 & 0.45 & 0.35 & 0.29 & 0.36 & 0.34 & 0.48 & 0.17 \\
\hline Latvia & 5644 & 2008-2010 & yes & 0.30 & 1.30 & 0.41 & 0.03 & 0.55 & 0.45 & 0.22 & 0.33 & 0.12 & 0.55 & 0.34 \\
\hline Poland & 10730 & 2008-2010 & yes & 0.23 & 1.66 & 0.53 & 0.04 & 0.52 & 0.41 & 0.24 & 0.34 & 0.07 & 0.62 & 0.31 \\
\hline Portugal & 4216 & 2008-2010 & yes & 0.78 & 2.57 & 0.48 & 0.02 & 0.49 & 0.27 & 0.30 & 0.43 & 0.59 & 0.22 & 0.19 \\
\hline Romania & 5269 & 2008-2009 & yes & 0.14 & 0.75 & 0.45 & 0.01 & 0.46 & 0.38 & 0.26 & 0.36 & 0.11 & 0.63 & 0.25 \\
\hline United Kingdom & 6866 & 2008-2010 & yes & 0.28 & 6.90 & 0.57 & 0.03 & 0.46 & 0.41 & 0.31 & 0.28 & 0.13 & 0.53 & 0.35 \\
\hline $\begin{array}{l}\text { Countries without a } \\
\text { national minimum wage }\end{array}$ & 8052 & - & no & 0.78 & 9.54 & 0.65 & 0.13 & 0.48 & 0.39 & 0.27 & 0.34 & 0.22 & 0.48 & 0.30 \\
\hline $\begin{array}{l}\text { Countries with national } \\
\text { minimum wage }\end{array}$ & 6263 & - & yes & 0.47 & 3.39 & 0.50 & 0.06 & 0.49 & 0.34 & 0.26 & 0.40 & 0.20 & 0.52 & 0.29 \\
\hline Total & 6792 & 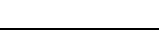 & - & 0.56 & 5.21 & 0.55 & 0.08 & 0.48 & 0.35 & 0.26 & 0.38 & 0.20 & 0.51 & 0.29 \\
\hline
\end{tabular}


Table 4: Sector-level regression with Kaitz Index as dependent variable

\begin{tabular}{|c|c|c|c|c|}
\hline & Model 1 & Model 2 & Model 3 & Model 4 \\
\hline National minimum wage (NMW) & $\begin{array}{c}0.04 \\
(0.03)\end{array}$ & $\begin{array}{c}0.03 \\
(0.04)\end{array}$ & $\begin{array}{c}-0.12 * * * \\
(0.01)\end{array}$ & $\begin{array}{c}-0.13^{* * *} \\
(0.02)\end{array}$ \\
\hline Collective bargaining cov. (CBC) & $\begin{array}{c}0.23 * * * \\
(0.04)\end{array}$ & $\begin{array}{c}0.31 * * * \\
(0.06)\end{array}$ & $\begin{array}{c}0.03 \\
(0.02)\end{array}$ & $\begin{array}{c}0.09 * * * \\
(0.03)\end{array}$ \\
\hline Interaction $\mathrm{NMW}^{*} \mathrm{CBC}$ & $\begin{array}{c}-0.30 * * * \\
(0.05)\end{array}$ & $\begin{array}{c}-0.30 * * * \\
(0.07)\end{array}$ & & \\
\hline \multicolumn{5}{|l|}{ Control variables: } \\
\hline Sex ratio & yes & & yes & \\
\hline Part-time ratio & yes & & yes & \\
\hline Share of public employment & yes & & yes & \\
\hline Age composition & yes & & yes & \\
\hline Educational composition & yes & & yes & \\
\hline Occupational composition & yes & & yes & \\
\hline Sector dummies & yes & & yes & \\
\hline Year dummies & yes & & yes & \\
\hline Constant & $\begin{array}{c}0.32 * * \\
(0.14) \\
\end{array}$ & $\begin{array}{c}0.47 * * * \\
(0.04) \\
\end{array}$ & $\begin{array}{c}0.43^{* * *} \\
(0.15) \\
\end{array}$ & $\begin{array}{c}0.61^{* * *} \\
(0.02) \\
\end{array}$ \\
\hline Adjusted R-squared & 0.67 & 0.21 & 0.65 & 0.18 \\
\hline Observations & 533 & 533 & 533 & 533 \\
\hline $\mathbf{F}$ & 50.14 & 37.61 & 44.32 & 52.58 \\
\hline $\mathbf{p}$ & 0.00 & 0.00 & 0.00 & 0.00 \\
\hline \multicolumn{5}{|c|}{$\begin{array}{l}\text { Sources: SILC waves 2008-2010; European Company Survey } 2009 \text { for collective bargaining } \\
\text { coverage at sector level; WSI Mindestlohndatenbank for statutory minimum wages; authors' } \\
\text { calculations. } \\
\text { Significance levels: } * \mathrm{p}<0.1, * * \mathrm{p}<0.05, * * * \mathrm{p}<0.01\end{array}$} \\
\hline
\end{tabular}


Table 5: Sector-level regression with share of workers below minimum wage as dependent variable

\begin{tabular}{|c|c|c|c|c|c|}
\hline & Model 5 & Model 6 & Model 7 & Model 8 & Model 9 \\
\hline National minimum wage (NMW) & $\begin{array}{c}0.12 * * * \\
(0.02)\end{array}$ & $\begin{array}{c}0.14^{* * *} \\
(0.02)\end{array}$ & $\begin{array}{c}-0.02 * * * \\
(0.00)\end{array}$ & $\begin{array}{c}-0.05^{* * * *} \\
(0.01)\end{array}$ & $\begin{array}{c}-0.05^{* * * *} \\
(0.01)\end{array}$ \\
\hline Collective bargaining cov. (CBC) & $\begin{array}{c}-0.05^{* *} \\
(0.02)\end{array}$ & $\begin{array}{l}-0.01^{*} \\
(0.01)\end{array}$ & $\begin{array}{l}-0.01 \\
(0.01)\end{array}$ & $\begin{array}{c}0.00 \\
(0.01)\end{array}$ & $\begin{array}{c}0.03 * * * \\
(0.01)\end{array}$ \\
\hline Interaction $\mathrm{NMW}^{*} \mathrm{CBC}$ & $\begin{array}{l}0.06^{* *} \\
(0.02)\end{array}$ & & & & \\
\hline Kaitz Index (KI) & $\begin{array}{c}0.44^{* * *} \\
(0.03)\end{array}$ & $\begin{array}{c}0.42^{* * *} \\
(0.03)\end{array}$ & $\begin{array}{c}0.28^{* * *} \\
(0.02)\end{array}$ & & \\
\hline Interaction NMW*KI & $\begin{array}{c}-0.30^{* * *} \\
(0.03)\end{array}$ & $\begin{array}{c}-0.28 * * * \\
(0.03)\end{array}$ & & & \\
\hline \multicolumn{6}{|l|}{ Control variables: } \\
\hline Sex ratio & yes & yes & yes & yes & \\
\hline Part-time ratio & yes & yes & yes & yes & \\
\hline Share of public employment & yes & yes & yes & yes & \\
\hline Age composition & yes & yes & yes & yes & \\
\hline Educational composition & yes & yes & yes & yes & \\
\hline Occupational composition & yes & yes & yes & yes & \\
\hline Sector dummies & yes & yes & yes & yes & \\
\hline Year dummies & yes & yes & yes & yes & \\
\hline \multirow[t]{2}{*}{ Constant } & $-0.11 *$ & $-0.13^{* *}$ & -0.08 & 0.04 & $0.07 * * *$ \\
\hline & $(0.06)$ & $(0.06)$ & $(0.07)$ & $(0.08)$ & $(0.01)$ \\
\hline R-squared & 0.78 & 0.77 & 0.68 & 0.48 & 0.18 \\
\hline Observations & 533 & 533 & 533 & 533 & 533 \\
\hline $\mathbf{F}$ & 36.93 & 36.49 & 18.68 & 11.83 & 34.17 \\
\hline p & 0.00 & 0.00 & 0.00 & 0.00 & 0.00 \\
\hline
\end{tabular}


Table 6: Robustness tests with Kaitz Index as dependent variable

\begin{tabular}{|c|c|c|c|c|c|c|}
\hline & $\begin{array}{c}\text { Baseline } \\
\text { model }\end{array}$ & $\begin{array}{c}\text { Model } 10 \\
\text { Sample } \\
\text { excluding sector } \\
\text { with Kaitz }>0.9 \\
\end{array}$ & $\begin{array}{l}\text { Model } 11 \\
\text { Sample } \\
\text { excluding } \\
\text { Belgium } \\
\end{array}$ & $\begin{array}{c}\text { Baseline } \\
\text { model }\end{array}$ & $\begin{array}{c}\text { Model } 12 \\
\text { Sample } \\
\text { excluding } \\
\text { sector with } \\
\text { Kaitz }>0.9 \\
\end{array}$ & $\begin{array}{c}\text { Model } 13 \\
\text { Sample } \\
\text { excluding } \\
\text { Belgium } \\
\end{array}$ \\
\hline & \multicolumn{3}{|c|}{ with interaction term } & \multicolumn{3}{|c|}{ without interaction term } \\
\hline National minimum wage (NMW) & 0.04 & 0.02 & 0.03 & $-0.12^{* * *}$ & $-0.09 * * *$ & $-0.13 * * *$ \\
\hline & $(0.03)$ & $(0.03)$ & $(0.03)$ & $(0.01)$ & $(0.01)$ & $(0.01)$ \\
\hline $\begin{array}{l}\text { Collective bargaining cov. } \\
\text { (CBC) }\end{array}$ & $0.23^{* * *}$ & $0.18^{* * *}$ & $0.22 * * *$ & 0.03 & 0.03 & 0.02 \\
\hline & $(0.04)$ & $(0.04)$ & $(0.04)$ & $(0.02)$ & $(0.02)$ & $(0.02)$ \\
\hline \multirow[t]{2}{*}{ Interaction $\mathrm{NMW}^{*} \mathrm{CBC}$} & $-0.30 * * *$ & $-0.22 * * *$ & $-0.31^{* * *}$ & & & \\
\hline & $(0.05)$ & $(0.05)$ & $(0.05)$ & & & \\
\hline \multicolumn{7}{|l|}{ Control variables: } \\
\hline Sex ratio & yes & yes & yes & yes & yes & yes \\
\hline Part-time ratio & yes & yes & yes & yes & yes & yes \\
\hline Share of public employment & yes & yes & yes & yes & yes & yes \\
\hline Age composition & yes & yes & yes & yes & yes & yes \\
\hline Educational composition & yes & yes & yes & yes & yes & yes \\
\hline Occupational composition & yes & yes & yes & yes & yes & yes \\
\hline Sector dummies & yes & yes & yes & yes & yes & yes \\
\hline Year dummies & yes & yes & yes & yes & yes & yes \\
\hline \multirow[t]{2}{*}{ Constant } & $0.32 * *$ & $0.43 * * *$ & $0.36^{* *}$ & $0.43 * * *$ & $0.52 * * *$ & $0.46^{* * *}$ \\
\hline & $(0.14)$ & $(0.14)$ & $(0.15)$ & $(0.15)$ & $(0.14)$ & $(0.16)$ \\
\hline R-squared & 0.67 & 0.63 & 0.68 & 0.65 & 0.61 & 0.65 \\
\hline Observations & 533 & 511 & 520 & 533 & 511 & 520 \\
\hline $\mathbf{F}$ & 50.14 & 43.32 & 48.26 & 44.32 & 41.84 & 42.30 \\
\hline p & 0.00 & 0.00 & 0.00 & 0.00 & 0.00 & 0.00 \\
\hline
\end{tabular}

Sources: SILC waves 2008-2010; European Company Survey 2009 for collective bargaining coverage at sector level; WSI

Mindestlohndatenbank for statutory minimum wages; authors' calculations.

Significance levels: $* \mathrm{p}<0.1, * * \mathrm{p}<0.05, * * * \mathrm{p}<0.01$ 
Table 7: Robustness tests with share of workers below minimum wage as dependent variable

\begin{tabular}{|c|c|c|c|c|c|c|}
\hline & Model 5 & \begin{tabular}{l}
\multicolumn{1}{|c}{ Model 14} \\
Sample \\
excluding \\
sector with \\
Kaitz $>0.9$ \\
\end{tabular} & $\begin{array}{l}\text { Sample } \\
\text { excluding } \\
\text { Belgium } \\
\end{array}$ & $\begin{array}{l}\text { Model } 16 \\
\text { Collective } \\
\text { bargaining } \\
\text { coverage } \\
\text { from } \\
\text { ICTWSS } \\
\end{array}$ & $\begin{array}{c}\text { Threshold } \\
\text { below MW = } \\
85 \%\end{array}$ & $\begin{array}{c}\text { Model } 18 \\
\text { Excluding } \\
\text { workers aged } \\
\text { below } 18 \text { years } \\
\text { and } \\
\text { apprentices } \\
\end{array}$ \\
\hline National minimum wage (NMW) & $\begin{array}{c}0.12 * * * \\
(0.02)\end{array}$ & $\begin{array}{c}0.07 * * * \\
(0.01)\end{array}$ & $\begin{array}{c}0.13 * * * \\
(0.02)\end{array}$ & $\begin{array}{l}0.04 * \\
(0.03)\end{array}$ & $\begin{array}{c}0.17 * * * \\
(0.02)\end{array}$ & $\begin{array}{c}0.14^{* * * *} \\
(0.02)\end{array}$ \\
\hline $\begin{array}{l}\text { Collective bargaining cov. } \\
\text { (CBC) }\end{array}$ & $\begin{array}{c}-0.05^{* *} \\
(0.02)\end{array}$ & $\begin{array}{l}-0.04 * \\
(0.02)\end{array}$ & $\begin{array}{c}-0.05^{* *} \\
(0.02)\end{array}$ & $\begin{array}{c}-0.14 * * * \\
(0.03)\end{array}$ & $\begin{array}{c}-0.05^{* * *} \\
(0.02)\end{array}$ & $\begin{array}{c}-0.05^{* *} \\
(0.02)\end{array}$ \\
\hline Interaction $\mathrm{NMW}^{*} \mathrm{CBC}$ & $\begin{array}{l}0.06^{* *} \\
(0.02)\end{array}$ & $\begin{array}{l}0.05^{* *} \\
(0.02)\end{array}$ & $\begin{array}{l}0.06 * * \\
(0.02)\end{array}$ & $\begin{array}{c}0.16^{* * * *} \\
(0.03)\end{array}$ & $\begin{array}{l}0.05^{* *} \\
(0.02)\end{array}$ & $\begin{array}{l}0.05^{* *} \\
(0.02)\end{array}$ \\
\hline Kaitz Index (KI) & $\begin{array}{c}0.44 * * * \\
(0.03)\end{array}$ & $\begin{array}{c}0.32 * * * \\
(0.04)\end{array}$ & $\begin{array}{c}0.44 * * * \\
(0.03)\end{array}$ & $\begin{array}{c}0.43^{* * *} \\
(0.03)\end{array}$ & $\begin{array}{c}0.57 * * * \\
(0.03)\end{array}$ & $\begin{array}{c}0.45^{* * *} \\
(0.03)\end{array}$ \\
\hline Interaction $\mathrm{NMW}^{*} \mathrm{KI}$ & $\begin{array}{c}-0.30 * * * \\
(0.03)\end{array}$ & $\begin{array}{c}-0.19 * * * \\
(0.03)\end{array}$ & $\begin{array}{c}-0.30 * * * \\
(0.03)\end{array}$ & $\begin{array}{c}-0.31 * * * \\
(0.03)\end{array}$ & $\begin{array}{c}-0.38^{* * * *} \\
(0.03)\end{array}$ & $\begin{array}{c}-0.30^{* * *} \\
(0.03)\end{array}$ \\
\hline \multicolumn{7}{|l|}{ Control variables: } \\
\hline Sex ratio & yes & yes & yes & yes & yes & yes \\
\hline Part-time ratio & yes & yes & yes & yes & yes & yes \\
\hline Share of public employment & yes & yes & yes & yes & yes & yes \\
\hline Age composition & yes & yes & yes & yes & yes & yes \\
\hline Educational composition & yes & yes & yes & yes & yes & yes \\
\hline Occupational composition & yes & yes & yes & yes & yes & yes \\
\hline Sector dummies & yes & yes & yes & yes & yes & yes \\
\hline Year dummies & yes & yes & yes & yes & yes & yes \\
\hline Constant & $\begin{array}{l}-0.11^{*} \\
(0.06) \\
\end{array}$ & $\begin{array}{r}0.01 \\
(0.06) \\
\end{array}$ & $\begin{array}{l}-0.12 * \\
(0.06) \\
\end{array}$ & $\begin{array}{c}0.01 \\
(0.06) \\
\end{array}$ & $\begin{array}{c}-0.17 * * * \\
(0.06) \\
\end{array}$ & $\begin{array}{c}-0.23^{* * *} \\
(0.06) \\
\end{array}$ \\
\hline R-squared & 0.78 & 0.64 & 0.78 & 0.79 & 0.84 & 0.78 \\
\hline Observations & 533 & 511 & 520 & 533 & 533 & 533 \\
\hline $\mathbf{F}$ & 36.93 & 28.50 & 35.02 & 41.78 & 54.89 & 32.17 \\
\hline $\mathbf{p}$ & 0.00 & 0.00 & 0.00 & 0.00 & 0.00 & 0.00 \\
\hline
\end{tabular}

Sources: SILC waves 2008-2010; European Company Survey 2009 and ICTWSS version 3.0 for collective bargaining coverage at sector level; WSI Mindestlohndatenbank for statutory minimum wages; authors' calculations.

Significance levels: ${ }^{*} \mathrm{p}<0.1,{ }^{* *} \mathrm{p}<0.05,{ }^{* * *} \mathrm{p}<0.01$ 
Table 8: Robustness tests with Kaitz Index as dependent variable

\begin{tabular}{|c|c|c|c|c|}
\hline & $\begin{array}{c}\text { Model } 1 \\
\text { Full sample }\end{array}$ & $\begin{array}{c}\text { Model } 19 \\
\text { Excluding workers } \\
\text { aged below } 18 \\
\text { years and } \\
\text { apprentices }\end{array}$ & Model 3 & $\begin{array}{c}\text { Model } 20 \\
\text { Excluding workers } \\
\text { aged below } 18 \\
\text { years and } \\
\text { apprentices }\end{array}$ \\
\hline & \multicolumn{2}{|c|}{ with interaction } & \multicolumn{2}{|c|}{ without interaction } \\
\hline National minimum wage (NMW) & $\begin{array}{c}0.04 \\
(0.03)\end{array}$ & $\begin{array}{c}0.05 \\
(0.03)\end{array}$ & $\begin{array}{c}-0.12^{* * *} \\
(0.01)\end{array}$ & $\begin{array}{c}-0.12^{* * *} \\
(0.02)\end{array}$ \\
\hline Collective bargaining cov. (CBC) & $\begin{array}{c}0.23^{* * *} \\
(0.04)\end{array}$ & $\begin{array}{c}0.23^{* * *} \\
(0.05)\end{array}$ & $\begin{array}{c}0.03 \\
(0.02)\end{array}$ & $\begin{array}{c}0.02 \\
(0.03)\end{array}$ \\
\hline Interaction $\mathrm{NMW}^{*} \mathrm{CBC}$ & $\begin{array}{c}-0.30 * * * \\
(0.05)\end{array}$ & $\begin{array}{c}-0.31 * * * \\
(0.05)\end{array}$ & & \\
\hline Control variables: & & & & \\
\hline Sex ratio & yes & yes & yes & yes \\
\hline Part-time ratio & yes & yes & yes & yes \\
\hline Share of public employment & yes & yes & yes & yes \\
\hline Age composition & yes & yes & yes & yes \\
\hline Educational composition & yes & yes & yes & yes \\
\hline Occupational composition & yes & yes & yes & yes \\
\hline Sector dummies & yes & yes & yes & yes \\
\hline Year dummies & yes & yes & yes & yes \\
\hline Constant & $\begin{array}{c}0.32 * * \\
(0.14) \\
\end{array}$ & $\begin{array}{c}0.38 * * \\
(0.19)\end{array}$ & $\begin{array}{c}0.43^{* * *} \\
(0.15)\end{array}$ & $\begin{array}{c}0.50^{* *} \\
(0.19)\end{array}$ \\
\hline R-squared & 0.67 & 0.66 & 0.65 & 0.63 \\
\hline Observations & 533 & 533 & 533 & 533 \\
\hline $\mathbf{F}$ & 50.14 & 44.28 & 44.32 & 39.32 \\
\hline $\mathbf{p}$ & 0.00 & $\mathbf{0 . 0 0}$ & 0.00 & $\mathbf{0 . 0 0}$ \\
\hline
\end{tabular}

Sources: SILC waves 2008-2010; European Company Survey 2009 for collective bargaining coverage at sector level; WSI Mindestlohndatenbank for statutory minimum wages; authors' calculations.

Significance levels: ${ }^{*} \mathrm{p}<0.1, * * \mathrm{p}<0.05,{ }^{* * *} \mathrm{p}<0.01$ 
Table 9: Robustness tests with Kaitz index as dependent variable

\begin{tabular}{|c|c|c|c|c|}
\hline & $\begin{array}{c}\text { Model } 1 \\
\text { Collective } \\
\text { bargaining } \\
\text { coverage } \\
\text { from ECS }\end{array}$ & $\begin{array}{c}\text { Model } 21 \\
\text { Collective } \\
\text { bargaining } \\
\text { coverage } \\
\text { from } \\
\text { ICTWSS }\end{array}$ & $\begin{array}{c}\text { Model } 3 \\
\text { Collective } \\
\text { bargaining } \\
\text { coverage } \\
\text { from ECS }\end{array}$ & $\begin{array}{c}\text { Model } 22 \\
\text { Collective } \\
\text { bargaining } \\
\text { coverage } \\
\text { from } \\
\text { ICTWSS }\end{array}$ \\
\hline & \multicolumn{2}{|c|}{ with interaction } & \multicolumn{2}{|c|}{ without interaction } \\
\hline National minimum wage (NMW) & $\begin{array}{c}0.04 \\
(0.03)\end{array}$ & $\begin{array}{c}-0.16^{* *} \\
(0.07)\end{array}$ & $\begin{array}{c}-0.12^{* * *} \\
(0.01)\end{array}$ & $\begin{array}{c}-0.08 * * * \\
(0.02)\end{array}$ \\
\hline Collective bargaining cov. (CBC) & $\begin{array}{c}0.23^{* * *} \\
(0.04)\end{array}$ & $\begin{array}{c}0.07 \\
(0.09)\end{array}$ & $\begin{array}{c}0.03 \\
(0.02)\end{array}$ & $\begin{array}{c}0.15^{* * *} \\
(0.03)\end{array}$ \\
\hline Interaction $\mathrm{NMW}^{*} \mathrm{CBC}$ & $\begin{array}{c}-0.30 * * * \\
(0.05)\end{array}$ & $\begin{array}{r}0.10 \\
(0.09) \\
\end{array}$ & & \\
\hline Control variables: & & & & \\
\hline Sex ratio & yes & yes & yes & yes \\
\hline Part-time ratio & yes & yes & yes & yes \\
\hline Share of public employment & yes & yes & yes & yes \\
\hline Age composition & yes & yes & yes & yes \\
\hline Educational composition & yes & yes & yes & yes \\
\hline Occupational composition & yes & yes & yes & yes \\
\hline Sector dummies & yes & yes & yes & yes \\
\hline Year dummies & yes & yes & yes & yes \\
\hline Constant & $\begin{array}{c}0.32 * * \\
(0.14) \\
\end{array}$ & $\begin{array}{c}0.45^{* * *} \\
(0.16)\end{array}$ & $\begin{array}{c}0.43^{* * *} \\
(0.15)\end{array}$ & $\begin{array}{c}0.35^{* *} \\
(0.14)\end{array}$ \\
\hline R-squared & 0.67 & 0.67 & 0.65 & 0.67 \\
\hline Observations & 533 & 533 & 533 & 533 \\
\hline $\mathbf{F}$ & 50.14 & 49.98 & 44.32 & 48.99 \\
\hline p & 0.00 & 0.00 & 0.00 & 0.00 \\
\hline
\end{tabular}

Sources: SILC waves 2008-2010; European Company Survey 2009 and ICTWSS version 3.0 for collective bargaining coverage at sector level; WSI Mindestlohndatenbank for statutory minimum wages; authors' calculations.

Significance levels: ${ }^{*} \mathrm{p}<0.1,{ }^{* *} \mathrm{p}<0.05,{ }^{* * *} \mathrm{p}<0.01$ 
Figure 1: Collective bargaining coverage and average Kaitz Indices by country and year

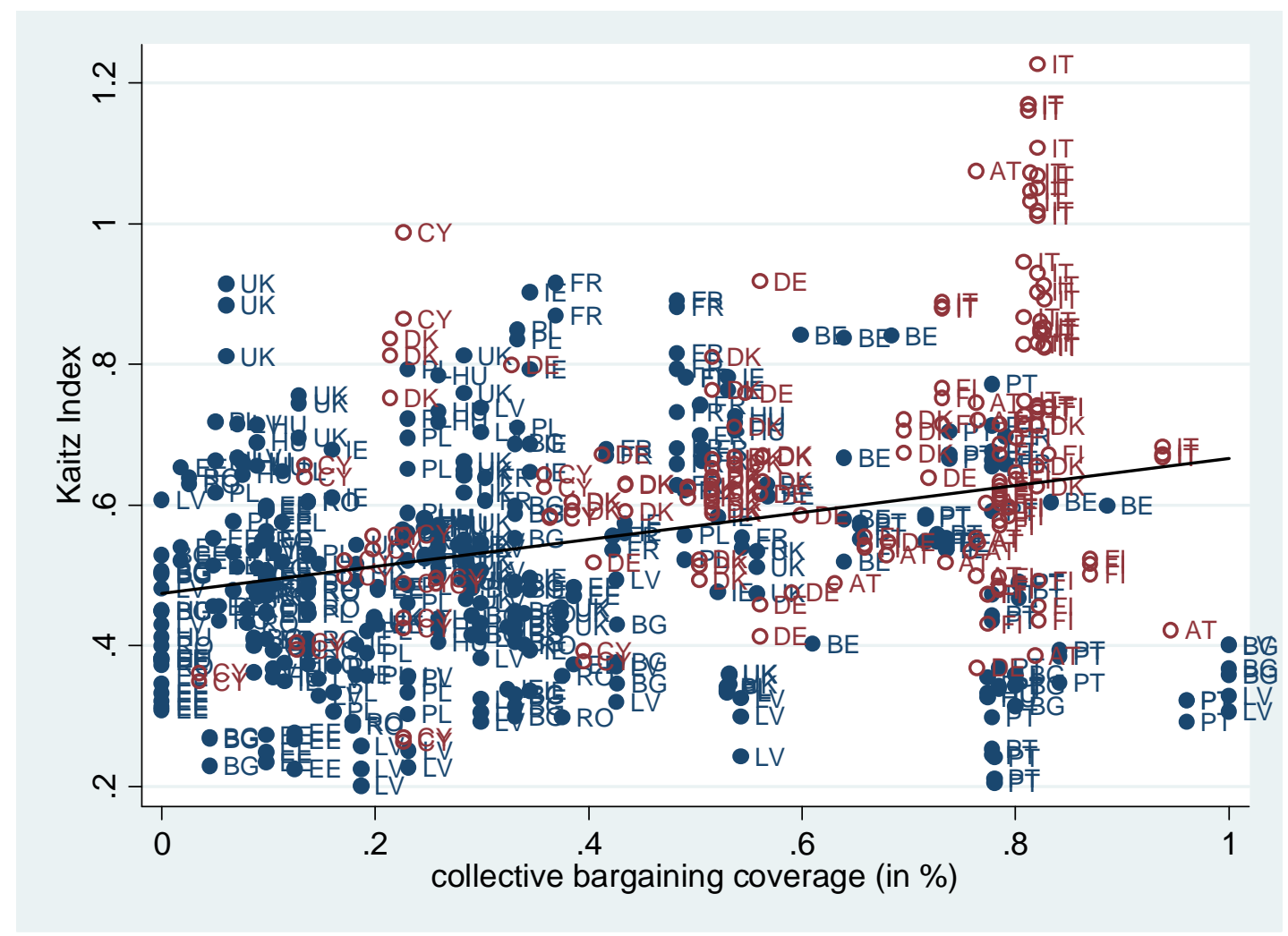

Sources: SILC waves 2008-2010; ECS; WSI Mindestlohndatenbank; authors’ calculations.

Note: Full dots represents sectors in countries with a statutory minimum wage, hollow dots represent sectors in countries without a statutory minimum wage. 
Figure 2: Sector-level shares of workers with wages at or below minimum wages and average Kaitz Indices

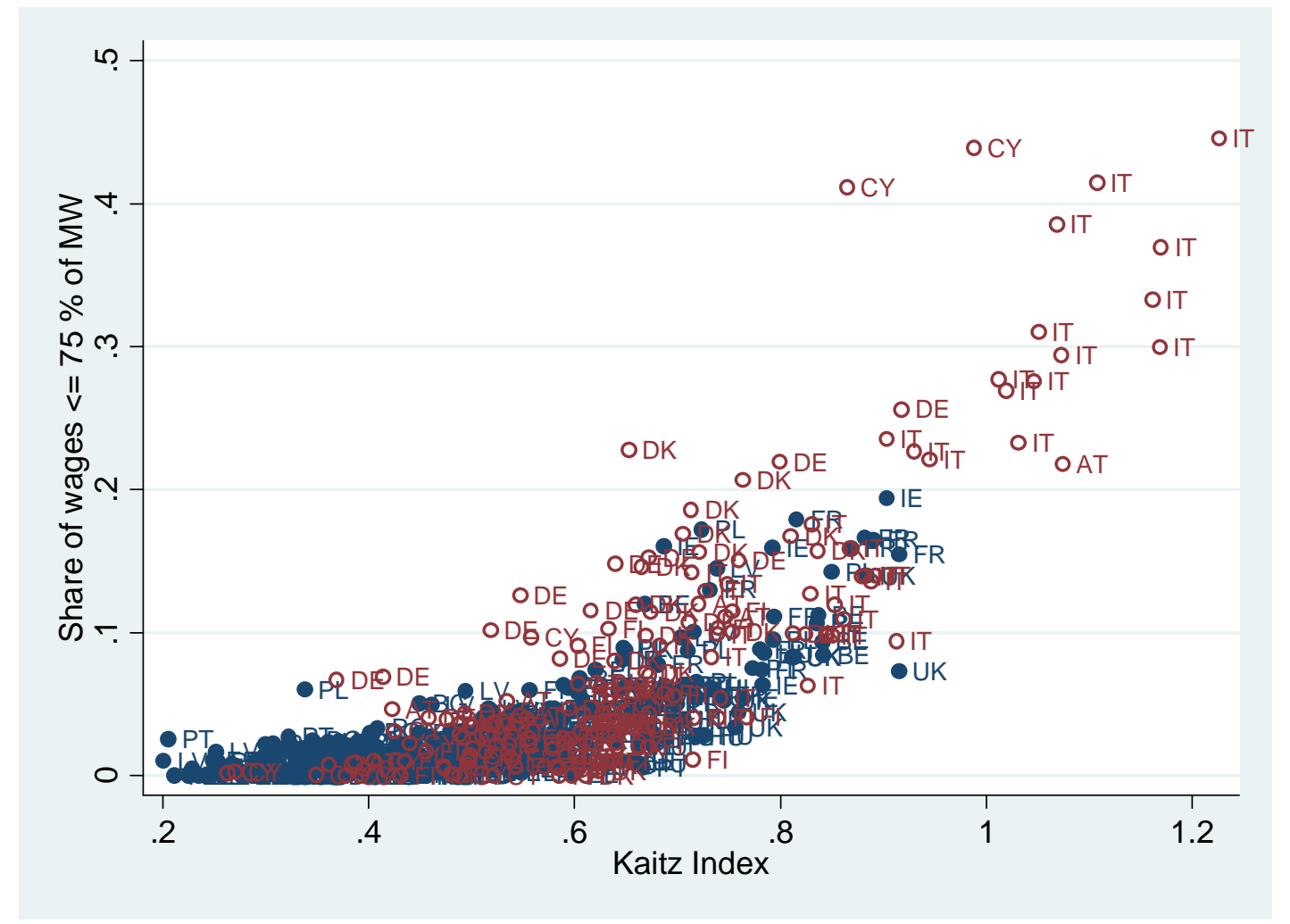

Sources: SILC waves 2008-2010; WSI Mindestlohndatenbank; authors' calculations. Note: Full dots represents sectors in countries with a statutory minimum wage, hollow dots represent sectors in countries without a statutory minimum wage. 


\section{Endotes}

\footnotetext{
${ }^{1}$ Brussels to push for EU-wide minimum wage policy, 17/4/2012, http://www.euractiv.com/socialeurope/brussels-push-eu-wide-minimum-wa-news-512189

${ }^{2}$ Rasmussen and Delors (2006) 'The New Social Europe', Report presented to the $7^{\text {th }}$ PES Congress, Porto, 7-8 December 2006.

${ }^{3}$ Notably the German Socio-Democratic Party (SPD) recently issued statements in favour of introducing a statutory minimum wage of 8,50 euros.

Mindestlohn, 27/3/2013, http://www.spdfraktion.de/themen/mindestlohn

4 'this hourly minimum wage corresponds to the lowest applicable level, namely to the position of an ordinary manual worker' [our translation].

5 'wages in collective agreements are minimim wages' [our translation].

6 'in Austrial the minimum wage represents the lowest pay category in the corresponding collective agreement' [our translation].

${ }^{7}$ Recent developments in Romania have, however, weakened the influence of collective bargaining, notably the introduction of the so-called Social Dialogue Act in 2011 (cf. Trif, forthcoming).

${ }^{8}$ See: http://www.boeckler.de/wsi-tarifarchiv_7052.htm

${ }^{9}$ Belgium actually has a national minimum wage, but in addition to this statutory floor the collectively bargained minimum wages constitute the relevant minimum for most workers. We have thus collected information on both the interprofessional and the sectoral-level minima and matched each individual to the minimum rate that corresponds to his or her profile. The inclusion of this special case in our sample has no consequences for the conclusions drawn from our empirical analysis (see robustness test in Section 4.3.13). ${ }^{10}$ Cyprus is a special case in that the minimum wage is not defined at the sectoral, but at the occupational level. For the period under analysis a single rate applied to around 10 occupational groups in Cyprus. We used data on these rates for 2007 and 2008 from EIRO country reports.

${ }^{11}$ A detailed description of the country specificities regarding the collection of sectoral-level data can be found in Kampelmann et al. (forthcoming). The sectoral data on collective bargaining coverage and minimum wages can be dowloaded at http://www.parisschoolofeconomics.eu/docs/garneroandrea/sector_mw_database_gkr2013.xls

${ }^{12}$ For a comparison of collective bargaining coverage from the ICTWSS and the ECS, see our robustness test in Section 4.3.4.

${ }^{13}$ The impact of alternative thresholds is discussed in Section 4.3.3.

${ }^{14}$ The results for the model with the proportion of workers below prevailing minimum are also robust to this test but have not been reported here due to space restrictions.

${ }^{15} \mathrm{http} / / /$ www.uva-aias.net/208; we used version 3.0 of this database.
} 